Volume 19 Number 2 December 2019 p.360-386

https://doi.org/10.30603/au.v19i2.848

\title{
Problems of Educators and Students in Learning Islamic Religious Education at Mts Pondok Darren Modern Darul Falah, Enrekang District
}

\author{
St Wardah Hanafie, Muhammad Siri Dangnga, Abdul Halik \& Jabal Rahmah \\ FAI Universitas Muhammadiyah Parepare \\ FKIP Universitas Muhammadiyah Parepare \\ Jurusan Tarbiyah Institut Agama Islam Negeri Parepare \\ Program Pascasarjana Universitas Muhammadiyah Parepare
}

\begin{abstract}
This article suggests the problematic of educators and students as learning actors so it is important to interact educative, conductively, effectively, and efficiently. Students as the next generation, it is important to be equipped with religious education (PAI) in order to have personality integrity. The success of students in PAI learning is influenced by creativity, commitment, dedication, and competence of educators implementing learning. It is important to examine the problem of educators and students in learning, the problem of learning Islamic education, and the solution to that problem. This research is Research and Development (R\&D). The research findings in the field show among others: the problem of educators is the complexity of the character of students; limited learning time; mastery of subject matter; availability of learning tools; limited learning infrastructure; mastery of learning strategies and methods; participation in scientific training and meetings; and the density of activities at the cottage. The problem of students is also monotonous learning strategies and methods; high teaching material; memorization strategy; motivation to compete; and lack of discipline.
\end{abstract}

\section{Problematika Pendidik dan Peserta Didik dalam Pembelajaran Pendidikan Agama Islam di MTS Pondok Pesantren Modern Darul Falah Kabupaten Enrekang}

\begin{abstract}
Abstrak
Artikel ini mengemukakan problematika pendidik dan peserta didik merupakan pelaku pembelajaran sehingga penting berinteraksi secara edukatif, kondusif, efektif, dan efisien. Peserta didik sebagai generasi penerus, penting dibekali pendidikan keagamaan (PAI) agar memiliki integritas kepribadian. Keberhasilan peserta didik dalam pembelajaran PAI dipengaurhi oleh kreativitas, komitmen, dedikasi, dan kompetensi pendidik melaksanakan pembelajaran. Hal tersebut penting dikaji problem pendidik dan peserta didik dalam pembelajaran, problem pembelajaran PAI, dan solusinya atas problem tersebut. Penelitian ini adalah Research and Development $(R \& D)$. Temuan di lapangan meliputi, yaitu: problem pendidik adalah kompleksitas karakter peserta didik; terbatasnya waktu pembelajaran; penguasaan materi pelajaran; ketersediaan perangkat pembelajaran; keterbatasan infrastruktur pembelajaran; penguasaan strategi dan metode pembelajaran; partisipasi kepada pelatihan dan pertemuan ilmiah; dan padatnya kegiatan di pondok; Problem peserta didik yaitu Strategi dan metode pembelajaran yang monoton; tingginya materi ajar; strategi menghafal; motivasi bersaing; dan kurang disiplin.
\end{abstract}

Kata Kunci:

problem, pendidik, peserta didik, pembelajaran.

Author correspondence

Email: wardahhadas@gmail.com, Muhammad.siri@gmail.com, abdulhaliknas@gmail.com, jabalrahmah@gmail.com _Available online at http://journal.iaingorontalo.ac.id/index.php/au/index 


\section{A. Pendahuluan}

Pendidikan memegang peranan yang menentukan eksistensi dan perkembangan masyarakat tersebut, oleh karena pendidikan merupakan usaha melestarikan, dan mengalihkan serta mentranfortasikan nilai-nilai kebudayaan dalam segala aspeknya dan jenisnya kepada generasi penerus. Pendidikan Islam dilihat dari segi kehidupan kultural umat manusia merupakan salah satu instrumen pembudayaan (enkulturasi) masyarakat itu sendiri. Sebagai suatu alat, pendidikan dapat difungsikan untuk mengarahkan pertumbuhan dan perkembangan hidup manusia, (sebagai makhluk pribadi dan sosial), kepada titik optimal kemampuannya untuk memperoleh kesejahteraan hidup di dunia dan kebahagiaan hidupnya di akhirat. Pendidikan agama Islam, secara umum belum menunjukkan hasil yang memuaskan yaitu menciptakan peserta didik yang berkualitas, yakni memiliki ilmu ilmiah, berakhlak mulia dan ikhlas beramal.

Persoalan pendidikan yang terkait dengan rendahnya mutu pendidikan pada setiap jenjang dan satuan pendidikan, khususnya pendidikan dasar dan menengah telah membangkitkan semangat berbagai pihak untuk meningkatkan kualitas pendidikan bukan merupakan masalah yang sederhana, tetapi memerlukan penanganan yang multidimensi dengan melibatkan berbagai pihak. ${ }^{1}$ Beragam program inovatif ikut serta memeriahkan reformasi pendidikan. Reformasi pendidikan adalah restrukturisasi pendidikan, yakni memperbaiki pola hubungan sekolah dengan lingkungan, pemerintah, pola pengembangan perencaan serta model-model pembelajaran. ${ }^{2}$

Undang-undang RI Nomor 20 Tahun 2003, tentang Sistem Pendidikan Nasional, Pasal 35 ayat 1 adalah Standar nasional terdiri terdiri atas standar isi, proses, kompetensi lulusan, tenaga kependidikan, sarana dan prasarana, pengelolaan, pembiayaan, dan penilaian pendidikan yang harus ditingkatkan secara berencana dan berkala. ${ }^{3}$ Pendidik yang disyaratkan oleh Undang-undang RI Nomor 14 Tahun 2005 tentang Pendidik dan Dosen untuk menjadi tenaga pengajar

\footnotetext{
${ }^{1}$ Muhammad Joko Susilo, Kurikulum Tingkat Satuan Pendidikan: Manajemen Pelaksanaan dan Kesiapan Sekolah Menyongsongnya(Cet. III; Yogyakarta: Pustaka Pelajar, 2008), h. 3.

${ }^{2}$ Abdul Majid, Perencanaan Pembelajaran; Mengembangkan Standar Kompetensi Guru(Cet. VII; Bandung: PT. Remaja Rosdakarya, 2011), h. 3.

${ }^{3}$ Undang-Undang RI Nomor 20 Tahun 2003, Sistem Pendidikan Nasional (Cet. IV; Jakarta: Sinar Grafika, 2011), h. 6.
} 
pada sekolah menengah atas harus memiliki kualifikasi akademik Strata Satu (S1). Hal ini ditegaskan pada Pasal 8 bahwa pendidik wajib memiliki kualifikasi akademik, kompetensi, sertifikat pendidik, sehat jasmani dan rohani, serta memiliki kemampuan untuk mewujudkan tujuan pendidikan Nasional. ${ }^{4}$

Pendidikan Islam mau tidak mau harus terlibat dalam mengatasi dan menyelesaikan berbagai tantangan tersebut bersama dengan kekuatan-kekuatan pendidikan nasional yang lain, bahkan bersamaan kekuatan sosial, politik dan ekonomi pada umumnya. Hanya saja pendidikan Islam perlu melakukan evaluasi diri terlebih dahulu untuk selanjutnya melakukan reaktualisasi dan reposisi, dengan cara melakukan sinkronisasi dengan kebijakan pendidikan nasional untuk membebaskan bangsa dari berbagai persoalan. ${ }^{5}$

Lembaga pendidikan Islam tidak hanya berkewajiban meningkatkan pencapaian akademis, tetapi juga bertanggungjawab dalam pembentukan karakter yang baik. Tuntutan ekonomi dan politik pendidikan menyebabkan penekanan pada pencapaian akademis mengalahkan idealitas peranan sekolah dalam pembentukan karakter. $^{6}$ Sekolah sebagai wadah pembentukan luaran yang berintegritas (karakter religius) yang paling efektif karena memiliki sumber daya yang memadai dan terorganisasi dengan baik. Realitasnya lembaga pendidikan terlalu mengedepankan orientasi aspek akademis, sehingga seringkali terabaikan aspek pengembangan karakter peserta didik. Kondisi ini membuat kreativitas peserta didik, keberanian menghadapi resiko, kemandirian, dan ketahanan melalui berbagai ujian hidup menjadi rendah. Anak mudah frustasi, menyerah, dan kehilangan semangat juang sampai titik darah penghabisan. ${ }^{7}$

Urgensi desain pembelajaran PAI dengan merelevansikan kompetensi pendidik dan potensi peserta didik sehingga dapat berimplikasi kepada pembentukan karakter religious pada peserta didik di MTs Darul Falah Kabupaten Enrekang

\footnotetext{
${ }^{4}$ Undang-Undang RI, Nomor 14 Tahun 2005, Guru dan Dosen (Cet. III; Jakarta: Sinar Grafika, 2010), h. 9.

${ }^{5}$ Muhaimin, Rekonstruksi Pendidikan Islam Ed. I, (Cet. I; Jakarta: Rajawali Pres, 2009), h. 17.

${ }^{6}$ Zubaiedi Desain Pendidikan Karakter: Konsepsi dan Aplikasinya dalam Lembaga Pendidikan (Jakarta: Kharisma Putera Utama, 2011), h. 14.

${ }^{7}$ Jamal Ma'mun Asmani, Buku Panduan Internalisasi Pendidikan Karakter di Sekolah (Yogyakarta: Diva Press, 2012), h. 26.
} 


\section{B. Metode}

Penelitian ini dilakukan di MTs Pondok Pesantren Darul Falah Enrekang Kabupaten Enrekang yang terletak di jalan Jendral Sudirman No. 2, Kabupaten Enrekang Provinsi Sulawesi Selatan. Penelitian ini merupakan penelitian lapangan (field research) yang bersifat deskriptif-kualitatif, yaitu mendeskripsikan secara sistematis, faktual, dan akurat terhadap suatu perlakuan pada wilayah tertentu mengenai pemahaman berdasarkan pengamatan terhadap suatu aspek, kemudian mendeskripsikan realitas rasional sebagai realitas subjektif melalui teknik analisis kualitatif. ${ }^{8}$

Langkah-langkah penelitian menggunakan pendekatan Research and Development (R \& D), yaitu (1) penelitian dan pengumpulan informasi, (2) perencanaan, (3) pengembangan bentuk awal produk, (4) uji lapang awal, (5) revisi utama produk, (6) uji lapang utama, (7) revisi produk operasional, (8) uji lapang operasional, (9) revisi produk akhir, dan (10) desiminasi dan implementasi. 9

Sumber data dalam penelitian ini adalah subjek dari mana data diperoleh. Untuk memudahkan peneliti untuk mengidentifikasi sumber data, maka diklasifikasi menjadi tiga bagian yang sering diistilahkan oleh Suharsimi Arikonto ${ }^{10}$ dengan 3P yaitu: person (sumber data berupa manusia), place (sumber data berupa tempat), dan sumber data berupa paper yaitu symbol. Lofland dalam Meleong ${ }^{11}$ mengatakan bahwa sumber data kualitatif ialah kata, dan tindakan, selebihnya adalah data tambahan seperti dan lain-lain. Sumber data penunjang dan pembelajaran yang terdapat di perpustakaan, hasil-hasil penelitian dalam bentuk tesis, serta file-file sekolah. Adapun instrumen dan teknik pengumpulan data adalah yang digunakan oleh peneliti di lapangan adalah pedoman wawancara, pedoman observasi dan catatan dokumentasi.

\footnotetext{
${ }^{8}$ Muhammad Arif Tiro, Penelitian: Skripsi, Tesis, dan Disertasi (Cet. I: Makassar: Andira Publisher, 2009), h. 123.

${ }^{9}$ Gall, Gall, \& Borg, Educational Research: An Introduction ( $7^{\text {th }}$ Edition, Boston: Allyn and Bacon, 2003), h. 261.

${ }^{10}$ Suharsimi Arikunto, Prosedur Penelitian: Suatu Pendekatan Praktik (Jakarta: Rineka Cipta, 2006), h. 129. h. 157.

${ }^{11}$ Lexy J. Moleong, Metodologi Penelitian Kualitatif (Bandung: PT. Remaja Rosdakarya, 2009),
} 
Analisis data kualitatif yang digunakan dalam model Miles and Huberman, yaitu data reduction, data display, dan conclusion drawing/verification. ${ }^{12}$ Analisis data pendekatan dilakukan dalam tiga alur kegiatan yang merupakan satu kesatuan (saling berkaitan) dan sistematis.

\section{Problema Pendidik dan Peserta didik dalam Pembelajaran PAI}

1. Problema Pendidik

Pendidik adalah orang yang bertanggungjawab dalam pembelajaran pada satuan pendidikan. Pendidik memiliki ekspektasi menjalankan tugasnya dapat berlangsung efektif dan efisien dalam mencapai tujuan. Keberhasilan pendidik menjalankan tugas pembelajaran berimplikasi kepada kualitas pendidikan di satuan pendidikan. Tingginya tanggungjawab pendidik, sehingga seringkali menemukan masalah dalam menjalankan tugasnya. Hal tersebut menjadi kajian problema pendidik dalam pembelajaran PAI pada Madrasah Tsanawiyah Pondok Pesantren Modern Darul Falah Enrekang.

Berdasaran observasi penelitian di lapangan, ditemukan bahwa pola interaksi antara pendidik dan peserta didik terjadi hubungan yang sangat erat dikarenakan pola kehidupan asrama sistem 24 jam tinggal di pondok membuat mereka sering bertemu dalam setiap aktifitas dan kegiatan yang ada. ${ }^{13}$ Padatnya kegiatan pendidik di pondok dan pendidik menjadi teladan dalam waktu 24 jam karena interaksi yang berlangsung siang malam. Informan menyebutkan bahwa "Salah satu problem bagi pendidik karena tinggal bersama dalam satu pondok. Hal tersebut terkadang masih ada oknum pendidik yang acuh tak acuh terhadap peserta didiknya dan ada beberapa oknum peserta didik yang secara karakter sangat tertutup sehingga menjadikan beberapa pendidik susah untuk memahami karakter peserta didik tersebut". ${ }^{14}$

\footnotetext{
${ }^{12}$ Lihat Sugiyono, Metode Penelitian Kuntitatif, Kualitatif, dan Kombinasi (Mixed Methods) (Cet, I; Bandung: Alfabeta, 2011), h. 249.

${ }^{13}$ Hasil observasi penelitian di MTs. Ponpes Modern Darul Falah Enrekang, Tanggal 02 September 2018.

${ }^{14}$ Hayatuddin, "Ketua Yayasan Pondok Pesantren Modern Darul Falah”, Wawancara, Enrekang, Tanggal 05 September 2018.
} 
Pembelajaran di pondok pesantren memiliki keunikan, karena di satu sisi dituntut mempertahankan tradisi, pada sisi lain penting beradaptasi dengan kemajuan yang ada. Pendidik memiliki misi mempertahankan identitas pondok pesantren, pada saat yang sama peserta didik (santri) cenderung mengikuti perkembangan khususnya di bidang teknologi informasi dan komunikasi. Kondisi ini yang sering ditemukan masalah oleh pendidik jika melaksanakan pembelajaran di kelas. Salah seorang informan menyatakan bahwa:

"Secara teori, para pendidik sebenarnya memiliki pemahaman yang utuh tentang strategi, metode, dan tekhnik pembelajaran, namun seringkali ketika di dalam kelas, pembelajaran yang sudah direncanakan tidak berjalan secara efektif dan efisien"15.

Pembelajaran di pondok pesantren dengan pola klasik bersifat monoton, dengan prinsip sami'na wa atha'na (kami mendengar dan kami mematuhi). Aspek lain, materi pelajaran di pondok pesantren yang bercirikan modern dinilai cukup padat karena aspek klasik dan modern yang disinergikan. Kondisi ini tampak menjadi masalah dalam pembelajaran karena peserta didik memiliki kepribadian yang beragam dengan type belajar yang bervariasi. Informan menyatakan bahwa: "Problem pembelajaran di pondok di antarnya adalah waktu yang sempit serta kegiatan yang padat menjadi salah satu penghalang penerapan metode dan strategi pembelajaran karena sedikit banyaknya tetap membutuhkan persiapan baik dari segi materi maupun alat peraga nantinya" 16.

Pendidik di Pondok Pesantren Darul Falah Enrekang biasanya melakukan pengembangan silabus dan RPP dan menerapkan di dalam kelas. Namun demikian, seringkali ketika pembelajaran berlangsung, silabus dan RPP tidak lagi menjadi rujukan utama, karena berbagai persoalan yang mengitari peserta didik. Itulah di pesantren, seribu satu masalah peserta didik dan yang lainnya yang semua disorot oleh pendidik. ${ }^{17}$ Konsistensi pendidik menjadikan silabus dan RPP sebagai rujukan di dalam pembelajaran merupakan suatu fenomena menarik di pondok pesantren. Ada factor lain yang dapat menjadi pemicu bagi pendidik, sehingga tidak terlalu

\footnotetext{
${ }^{15}$ Misran, Kepala MTs. Ponpes Modern Darul Falah Enrekang, Wawancara, Enrekang, Tanggal 05 September 2018.

${ }^{16}$ Nasan, "Pendidik PAI", wawancara, Enrekang, Tanggal 14 September 2018.

${ }^{17}$ Darwin, "Pendidik PAI", Wawancara, Enrekang, Tanggal 12 September 2018.
} 
peduli terhadap kualitas silabus dan RPP. Salah seorang informan menyatakan bahwa:

"Status pendidik sebagai non PNS ternyata sangat berpengaruh besar
terhadap perhatian dan penyusunan kelengkapan administrasi, seperti
silabus dan RPP. Ada anggapan bahwa kebutuhan admnintrasi itu hanya
dbutuhkan dan diperuntukkan untuk pendidik ASN. Ditambah lagi dengan
pelaksanaan MGMP pada tingkat sekolah kurang efektif dan jarang
dilaksanakan".18

Status pendidik di pondok pesantren yang non-ASN menjadi salah satu factor perhatian terhadap perangkat pembelajaran. Tidak adanya tuntutan dan kewajiban secara formal berdampak kepada perhatian pendidik dalam mempersiapkan perangkat pembelajaran secara administratif. Pendidik dipondok merupakan orang-orang yang tidak terikat dalam ASN dan teruji dalam totalitas pengabdian kepada anak bangsa. Hanya saja ada persiapan administratif perangkat pembelajaran jika ingin diakreditasi sebagai prasyarat pengakuan kualitas dari pemerintah dan masyarakat.

Permasalahan selanjutnya yang dialami pendidik dalam melaksanakan pembelajaran adalah keterbatasan sarana dan prasarana pembelajaran. Keterangan yang sama dijelaskan oleh Wakasek bidang Kurikulum Madrasah Tsanawiyah Pondok Pesantren Modern Darul Falah Enrekang bahwa:

Sarana dan prasana sekolah menjadi salah satu penunjang pokok dalam suksenya pembejalaran yang ada. Perencanaan yang ada terkadang terkendala dalam proses pelaksaannya di lapangan apabila terbentur dengan ketersiadaan alat peraga misalnya kebutuhan laboratorium maupun kebutuhan alat pegara lainnya. ${ }^{19}$

Sarana dan prasarana sebagai pendukung utama keberhasilan pembelajaran. Pondok pesantren modern memiliki kurikulum yang terintegrasi, yakni kurikulum pesantren dan nasional, sehingga membutuhkan fasilitas yang memadai untuk mengakomodir kebutuhan kurikulum tersebut. Sistem pembelajaran di Pondok Pesantren berbasis pendidikan intergratif yaitu pendidikan yang memadukan antara pendidikan agama dan pendidikan umum yang diharapkan.

\footnotetext{
${ }^{18}$ Darwin, "Pendidik PAI", Wawancara, Enrekang, Tanggal 12 September 2018.

${ }^{19}$ Azlinda, "Wakil Kepala Sekolah Bidang Kurikulum MTs. Ponpes Modern Darul Falah Enrekang, Wawancara, Enrekang, tanggal 12 September 2018.
} 
Permasalahan selanjutnya yang dialami pendidik di pondok pesantren adalah penguasaan materi pembelajaran. Azlinda sebagai Wakil Kepala Sekolah Bidang Kurikulum Madrasah Tsanawiyah Pondok Pesantren Modern Darul Falah Enrekang mengatakan:

Tantangan pendidik di pondok pesantren adalah kemampuan mengartikulasikan ajaran Islam yang sesuai dinamika zaman dan bersifat fungsional kepada peserta didik. Penguasaan materi oleh pendidik menjadi sebuah tuntutan besar, karena semakin kompleks masalah hidup maka semakin dibutuhkan keluasan dan kedalaman ilmu untuk menemukan solusi yang tepat dan relevan. ${ }^{20}$

Keterangan di atas menunjukkan bahwa pendidik Pondok Pesantren dituntut selalu meng-up grade ilmu pengetahuan dan dinamika zaman. Pendidik yang memahami kompleksitas di era disrupsi 4.0 ini, akan mampu menjawab zaman berdasarkan kebutuhan peserta didik dalam membangun masa depannya. Keterangan informan, Darwin sebagai pendidik Pendidikan Agama Islam Madrasah Tsanawiyah Pondok Pesantren Modern Darul Falah Enrekang, bahwa:

Masalah yang sering dialami pendidik adalah ketinggalan informasi dan semakin kompleksnya ilmu pengetahuan. Islam dinilai hanya sebagai kontrol moral atas kemajuan dan bukan menjadi sumber lahirnya peradaban dan solusi bagi masyarakat. Sejatinya pendidik harus lebih aktif dan responsif terhadap dinamika, membaca aspek psikologis peserta didik, dinamika sosial kultural, dan Islam menjadi perisai atas semua transformasi hidup. ${ }^{21}$

Terkait dengan penguasaan materi pembelajaran PAI, peneliti melalui observasi di lapangan menemukan data bahwa pendidik membahas tentang shalat lima waktu, termasuk tata cara pelaksanaannya tidak dijelaskan secara rinci, sehingga peserta didik bingung dan kemudian bertanya tentang tata cara masbuk. Saat itu pendidik PAI memberikan penjelasan yang tidak sesuai dengan pertanyaan peserta didik. Seringkali pendidik berupaya mengkaji secara general tetapi lupa yang spesifik, begitu juga mengkaji yang spesifik tetapi terlewatkan yang bersifat general dan universal.

Permasalahan yang dialami pendidik di Pondok Pesantren adalah penguasaan terhadap strategi dan pembelajaran di kelas. Pengakuan Kepala Madrasah Tsanawiyah Pondok Pesantren Modern Darul Falah, bahwa: "Tidak bisa

\footnotetext{
${ }^{20}$ Azlinda, "Wakil Kepala Sekolah Bidang Kurikulum MTs. Ponpes Modern Darul Falah Enrekang, Wawancara, Enrekang, tanggal 12 September 2018.

${ }^{21}$ Darwin, "Pendidik PAI", Wawancara, Enrekang, Tanggal 12 September 2018.
} 
dipungkiri keadaan sebagian pendidik di sini masih minim penguasaan strategi dan metode. Hal ini tetap menjadi bahan evaluasi untuk kami sebagai pendidik di Pondok Pesantren"22. Penguatan dan penguasaan bidang strategi dan metode pembelajaran dipengaruhi oleh intensitas pendidik mengikuti pelatihan, sharing dengan pendidik dalam MGMP, dan atau studi lanjut. Namun demikian, pendidik di Pondok Pesantren berdasarkan observasi di lapangan bahwa jarang mengikuti pelatihan bidang pembelajaran, tidak aktif di MGMP, tetapi sebagian lanjut ke jenjang pendidikan Magister.

Sistem pendidikan di Madrasah Tsanawiyah Pondok Pesantren Modern Darul Falah Enrekang adalah berjalan selama 24 jam. Interkasi antara kiai, ustadz, dan santri berjalan sangat intens. Interaksi dalam pendidikan tersebut dibangun di atas pondasi akhlak al-karimah. Di samping itu juga untuk mewadahi bakat dan minat para santri, pesantren juga memfasilitasi dengan beragam kegiatan ekstrakulkuler seperti badminton, menjahit, kaligrafi, bela diri, panahan, tilawah dan masih banyak kegiatan yang lain. Pendidk Madrasah Tsanawiyah Pondok Pesantren Modern Darul Falah memiliki aktivitas dan tanggung jawab yang tidak kalah penting dengan aktivitas mengajar di kelas. informan menegaskan bahwa: "Kami memiliki aktivitas menpendidiks peserta didik selama 24 jam. Bukan saja yang dilayani masalah pembelajaran di kelas, tetapi juga kegiatan pondok bersifat formal, mengontrol peserta didik selama di pondok, dan aktivitas di luar kegiatan kurikuler dan ekstrakurikuler seperti kegiatan di asrama dan di masjid. Di samping, sebagai kepala rumah tangga juga berusaha mencari rezeki tambahan di luar pondok".23

Pendidik di Pondok Pesantren merupakan orang-orang yang memiliki kesiapan mental dan totalitas menpendidiks umat. Kesibukan melayani anak didik selama di pondok pesantren seringkali tersita waktunya untuk persiapan administrasi pembelajaran di kelas. Hal tersebut berdasarkan observasi di lapangan bahwa terbatasnya jumlah pendidik yang kurang seimbang dengan jumlah peserta didik. Kemudian kemampuan Yayasan Pondok Pesantren

\footnotetext{
${ }^{22}$ Misran, Kepala MTs. Ponpes Modern Darul Falah Enrekang, Wawancara, Enrekang, Tanggal 05 September 2018.

${ }^{23}$ Nasan, "Pendidik PAI", wawancara, Enrekang, Tanggal 14 September 2018.
} 
memberikan insentif yang layak kepada pendidik, yang memungkinkan pendidik harus mencari tambahan rezeki di luar pondok, seperti berkebun, berbisnis, mengadakan kursus Bahasa, atau berdakwah.

Berdasarkan pembahasan di atas maka dapat disimpulkan bahwa problematika yang dihadapi dan dialami pendidik di Madrasah Tsanawiyah Pondok Pesantren Modern Darul Falah Kab. Enrekang, adalah:

1) Kompleksitas karakter peserta didik termasuk bakat dan minat yang menjadi penghambat pelaksanaan pembelajaran di kelas;

2) Terbatasnya waktu pembelajaran di kelas sedangkan materinya padat;

3) Penguasaan pendidik terhadap materi pelajaran secara detail dan spesifik karena kekhasannya di pondok pesantren adalah sinergitas klasik dan modern;

4) Ketersediaan administrasi pendidik seperti Silabus, RPP, dan lainnya yang tidak tersedia secara optimal karena semuanya pendidik non-ASN;

5) Keterbatasan sarana dan prasarana pembelajaran khususnya yang berbasis Teknologi Informasi dan Komunikasi (TIK);

6) Pendidik terbatas menguasai strategi dan metode pembelajaran;

7) Rendahnya keikutsertaan pendidik mengikuti pelatihan dan pertemuan pada organisasi profesi kependidikan;

8) Pendidik memiliki waktu yang padat membina peserta didik di pondok pesantren.

2. Problema Peserta didik

Peserta didik (disebut santri di pondok) merupakan orang-orang yang belajar di pondok pesantren dan membutuhkan layanan optimal agar dapat berkembang secara positif dan kreatif menuju ke dewasaannya. Kompleksnya masalah peserta didik di pondok pesantren sehingga dibutuhkan perhatian massif oleh pendidik dan pimpinan pondok pesantren. Berikut diuraikan masalah yang dihadapi oleh peserta didik di pondok pesantren terkait pembelajaran, yaitu:

Permasalahan yang dirasakan peserta didik dalam mengikuti pembelajaran adalah padatnya jam pelajaran di pondok pesantren. Berikut penjelasan informan peserta didik, bahwa:

Di sini, kita belajar pendidikan umum dan pendidikan agama. Pelajarannya bagus dan pendidiknya juga bagus. Hanya saja terkadang banyak sekali pelajaran yang harus dihapal yang kadang membuat saya memaksa diri belajar. $^{24}$

\footnotetext{
${ }^{24}$ Rafika Djafar, Santriwati MTs. Ponpes Moder Darul Falah Enrekang, Wawancara, Enrekang, Tanggal 06 September 2018.
} 
Peserta didik memiliki keterbatasan kemampuan dalam mengikuti pembelajaran, karena di Pondok Pesantren Modern ini memiliki kurikulum umum (K13) dan kurikulum pondok. Salah satu solusi yang dapat dilakukan pendidik adalah memperbaiki strategi dan metode pembelajaran di dalam kelas. kompetensi pendidik dalam konteks ini menekankan aspek pedagogic, yakni kemampuan pendidik dalam menyajikan materi ajar yang sesuai dengan kebutuhan peserta didik. Salah seorang informan peserta didik menyatakan bahwa: "Kadang saya susah memahami pelajaran yang ada, karena keseringan ustadznya hanya menjelaskan di depan hanya sesekali praktik dan memberi contoh". ${ }^{25}$ Selanjutnya, salah seorang peserta didik sebagai informan, menjelaskan bahwa: "Saya suka sekali dengan pelajaran Aqidah Akhlak, Fiqh, Quran Hadis dan SKI, hanya saja saya sering bingung ketika materinya sudah tingkat tinggi, saya hanya dapat menghayal dan membayangkan saja utamanya pada pembahasan pelajaran pelajaran fiqh". 26 Informan lain juga menambahkan bahwa: "Permasalahan dalam pembelajaran adalah metode mengajar pendidik yang sebagian besar waktunya hanya untuk mencatat pelajaran dan ceramah, sehingga sangat membosankan. ${ }^{27}$

Keterangan dari informan di atas mendeskripsikan masalah yang dihadapi peserta didik adalah minat dan motivasi mengikuti pembelajaran di kelas. Pendidik seringkali tidak menyadari keluhan peserta didik karena tidak ada instrument refleksi pembelajaran di kelas. Realitas ini menunjukkan bahwa peserta didik membutuhkan pembelajaran yang menyenangkan, membangkitkan minat dan motivasi, serta transmisi materi ajar yang terjangkau oleh nalar peserta didik. Keluhan lain yang disampaikan oleh peserta didik sebagai informan adalah: "Saya kurang bersemangat belajar PAI, karena belum fasih mengaji, lalu banyak materi hafalan yang susah untuk dihafalkan".28 Lebih lanjut dikatakan Rezky

\footnotetext{
${ }^{25}$ Djeni Febriana, Santriwati MTs. Ponpes Moder Darul Falah Enrekang, Wawancara, Enrekang, Wawancara, Enrekang, Tanggal 06 September 2018.

${ }^{26}$ Djeni Febriana, Santriwati MTs. Ponpes Moder Darul Falah Enrekang, Wawancara, Enrekang, Wawancara, Enrekang, Tanggal 06 September 2018.

${ }^{27}$ Amel Aisyah Ihya, Santriwati MTs. Ponpes Moder Darul Falah Enrekang, Wawancara, Enrekang, Wawancara, Enrekang, Tanggal 17 September 2018.

${ }^{28}$ Aisyah Salsabilah, Santriwati MTs. Ponpes Moder Darul Falah Enrekang, Wawancara, Enrekang, Wawancara, Enrekang, Tanggal 17 September 2018.
} 
Alfianti peserta didik kelas VII B bahwa "Saya sudah bisa mengaji tetapi terkendala di persoalan hafalan yang agak banyak diberikan di setiap mata pelajaran PAI."29

Keterangan tersebut menunjukkan bahwa kendala atau masalah yang besar yang dihadapi oleh peserta didik adalah menghafal. Menghafal dengan cara santai dan rileks merupakan strategi yang diharapkan peserta didik sehingga memiliki motivasi untuk melakukannya. Tidak semua peserta didik memiliki kemampuan menghafal, sehingga pendidik dapat menerapkan strategi efektif agar peserta didik tergugah untuk menghafal. Minat dan motivasi menghafal, seringkali peserta didik dipengaruhi oleh teman-temannya di pondok pesantren karena ada persaingan. Namun demikian, ada factor sosiologis juga tidak menjadi motivator untuk menghafal karena peserta didik berasal dari rumpun yang sama, yakni dari Kabupaten Enrekang. Salah seorang informan menyatakan bahwa:

Kami dari peserta didik memiliki latar belakang yang sama, seperti kampong, Bahasa, budaya, dan bahkan tradisi yang sama. Bagi kami mondok di pesantren seperti berada di kampung sendiri. Kemudian, pendidik di sini rata-rata warga lokal menambah suasana yang nyaman. Tetapi kelemahannya kami tidak termotivasi untuk bersaing secara sehat, seperti menghafal paling banyak, karena para pesaing adalah teman dan keluarga kita sendiri. Jadi menurut saya, ada kendala untuk mengembangkan semangat belajar karena factor satu rumpun. ${ }^{30}$

Keterangan di atas dapat dibenarkan karena jika peserta didik berasal dari budaya yang beragam dan majemuk, maka dalam interaksi terjadi saling mengisi, sharing pemikiran, bahkan saling bersaing. Dampak lainnya kalau satu rumpun adalah tidak adanya saling memberi informasi kepada pendidik jika ada peserta didik yang melanggar aturan, seperti bolos sekolah, tidak mengerjakan tugas, lambat masuk ke kelas, dan sebagainya. Begitu juga masalah kedisiplinan di pondok, kadang menjadi hambatan dalam mengikuti pembelajaran di kelas. salah seorang informan menyatakan bahwa: "Saya terkadang terlambat masuk kelas karena kami harus antri mandi di asrama, karena kegiatan di mesjid lambat selesai". 31

\footnotetext{
${ }^{29}$ Rezky Alfianti, Santriwati MTs. Ponpes Moder Darul Falah Enrekang, Wawancara, Enrekang, Wawancara, Enrekang, Tanggal 17 September 2018.

${ }^{30}$ Amel Aisyah Ihya, Santriwati MTs. Ponpes Moder Darul Falah Enrekang, Wawancara, Enrekang, Wawancara, Enrekang, Tanggal 17 September 2018.

${ }^{31}$ Rafika Djafar, Santriwati MTs. Ponpes Moder Darul Falah Enrekang, Wawancara, Enrekang, Tanggal 06 September 2018.
} 
Keterangan dan pembahasan di atas dapat dikatakan bahwa permasalahan peserta didik cukup banyak ditemukan di pondok pesantren. Adapun masalah peserta didik yang teridentifikasi selama dalam penelitian ini adalah:

1) Strategi dan metode pembelajaran yang monoton;

2) Peserta didik yang tidak terjangkau nalarnya terhadap pembelajaran;

3) Peserta didik belum mendapatkan cara menghafal;

4) Motivasi bersaing dinilai rendah karena peserta didik yang tidak majemuk;

5) Lambat masuk belajar karena terbatas sarana di pondok.

\section{Faktor Pendukung dan Penghambat Pembelajaran PAI}

\section{Faktor pendukung}

Pondok pesantren memiliki sistem pembelajaran yang unik dan kekhasan, sehingga kegiatan pembelajaran PAI memiliki peluang berjalan efektif dan efisien. Berikut factor pendukung pembelajaran PAI di Pondok Pesantren Modern Darul Falah Enrekang, yaitu:

a) Sistem pembelajaran 24 jam

Sistem pembelajaran di pondok pesantren adalah sistem 24 jam, artinya segala akivitas peserta didik bagian dari pendidikan dan pembelajaran. Ketua Yayasan Pondok Pesantren Modern Darul Falah menyatakan bahwa "tidak ada kegiatan yang sia-sia yang dikerjakan oleh peserta didik kita di sini, semua bernilai positif di samping memberikan pelajaran hidup juga melatih kesabaran dan kemandirian peserta didik sehingga diharapkan akan muncul generasi-generasi yang kuat yang mampu bersaing dengan dunia global saat ini". ${ }^{2}$ Selanjutnya, informan lain menyatakan bahwa "Segala aktivitas yang ada di pesantren ini telah didesain sedemikian rupa sehingga menjadi kondusif untuk tempat menimba ilmu".33

Peserta didik tinggal atau mondok di pesantren, segala tindak tanduknya berada dalam pengawasan pendidik. Informan peserta didik menyatakan bahwa "mulai dari bangun tidur sampai tidur kembali di sini kita belajar terus, tidak

\footnotetext{
${ }^{32}$ Hayatuddin, "Ketua Yayasan Pondok Pesantren Modern Darul Falah”, Wawancara, Enrekang, Tanggal 05 September 2018.

${ }^{33}$ Misran, Kepala MTs. Ponpes Modern Darul Falah Enrekang, Wawancara, Enrekang, Tanggal 05 September 2018.
} 
pernah berhenti". ${ }^{44}$ Keterangan tersebut menunjukkan bahwa pembelajaran PAI di pondok pesantren lebih banyak pada pendekatan pembiasaan dan keteladanan secara langsung dalam kehidupan sehari-hari. Pembelajaran yang bersifat teori, peserta didik dapat menerima di dalam kelas dan di masjid.

b) Dana bantuan dari Yayasan

Berdasarkan studi dokumen di pondok pesantren, menunjukkan bahwa Madrasah Tsanawiyah Pondok Pesantren Modern Darul Falah Enrekang, selain mendapat bantuan dari yayasan yang cukup besar, juga mendapatkan bantuan dari pemerintah, seperti dana bos dan dana gratis. Informan dari Kepala Madrasah Tsanawiyah menyatakan bahwa: "Kami di sekolah sudah mendapat bantuan dari pemerintah berupa dana bos dan dana gratis dan bagi kami itu sebenrnya sudah cukup untuk melakukan pembelajaran, tapi karena kita di bawah yayasan, bantuan pun mengalir untuk kegiatan pembelajaran khususnya PAI". ${ }^{35}$ Keterangan tersebut menunjukkan bahwa biaya operasional pembelajaran PAI di Pondok Pesantren memiliki anggaran yang cukup dan memadai.

c) Kegiatan ektrakulikuler

Kegiatan ekstrakulikuler adalah kegiatan non pelajaran formal yang dilakukan oleh peserta didik di sekolah, umumnya di luar jam belajar kurikulum standar. Berdasarkan hasil observasi di lapangan bahwa: "Kegiatan ekstrakulikuler di Pondok Pesantren berjalan dengan intens dengan program tambahan berupa pengembangan kepribadian, bakat, dan kecakapan di berbagai bidang di luar bidang akademik. Kegiatan ekstrakulikuler ini diadakan dapat berbentuk kegiatan pada seni, olahraga, pengembangan kepribadian, dan kegiatan kegiatan lain yang bertujuan positif". ${ }^{36}$ Keterangan tersebut menegaskan peserta didik memiliki kegiatan pendidikan yang sejalan dengan orientasi PAI di pondok pesantren.

\footnotetext{
${ }^{34}$ Rafika Djafar, Santriwati MTs. Ponpes Moder Darul Falah Enrekang, Wawancara, Enrekang, Tanggal 06 September 2018.

${ }^{35}$ Misran, Kepala MTs. Ponpes Modern Darul Falah Enrekang, Wawancara, Enrekang, Tanggal 05 September 2018.

${ }^{36}$ Misran, Kepala MTs. Ponpes Modern Darul Falah Enrekang, Wawancara, Enrekang, Tanggal 05 September 2018.
} 
Problems of Educators and Students in Learning Islamic Religious Education at Mts Pondok Darren Modern Darul Falah, Enrekang District

2. Faktor penghambat

a) Pengelolaan kelas

Berdasarkan hasil observasi, bahwa lingkungan kelas kurang tertata dengan baik, karena penuh dengan kursi sehingga ruang gerak peserta didik dan pendidik terbatas, sehingga proses pembelajaran kurang menyenangkan. Akibatnya peserta didik sering keluar masuk kelas untuk menyegarkan badan karena di dalam kelas mereka duduk berdekatan antara satu dengan yang lainnya. Suasana seperti ini tidak menyenangkan untuk melakukan proses pembelajaran yang menyenangkan, karena selain ribut juga suasana kelas panas.

Deskripsi kualitas pembelajaran PAI pada indikator pengelolaan kelas tersebut di atas dapat dibandingkan dengan hasil wawancara yang menyatakan bahwa:

Dalam pengelolaan kelas, baik susunan kursi, bangku, peserta didik maupun tata ruang kelas penting dilakukan untuk menciptakan suasana kelas yang aman, nyaman dan kondusif. Dalam tataran konsep tentang pengelolaan kelas memang harus dilakukan oleh pendidik. Menurut saya, sebagian besar pendidik melaksanakan pengelolaan kelas dengan baik. Namun, masih ada beberapa pendidik masuk kelas kemudian langsung memulai proses pembelajaran tanpa mengelola kelas terlebih dahulu. ${ }^{37}$

Pernyataan di atas sesuai dengan pernyataan Kepala Madrasah Tsanawiyah

Pondok Pesantren Modern Darul Falah, bahwa:

Pengelolaan kelas, dalam proses pembelajaran yang efektif harus dilakukan oleh seorang pendidik. Karena tanpa pengelolaan kelas dengan baik, akan berdampak pada kenyamanan dan ketentraman proses pembelajaran dalam kelas. Permasalahan ini merupakan kenyataan bahwa pendidik harus mampu menciptakan tatanan pembelajaran yang efektif melalui pengelolaan kelas dengan benar. ${ }^{38}$

Keterampilan mengelola kelas merupakan keterampilan dalam menciptakan dan mempertahankan kondisi kelas yang optimal guna terciptanya proses pembelajaran yang efektif dan efisien. Hal inilah menjadi persoalan mendasar dalam pelaksanaan pembelajaran PAI di kelas secara efektif dan efisien, yang perlu mendapat perhatian serius dari pendidik.

\footnotetext{
${ }^{37}$ Nasan, "Pendidik PAI", wawancara, Enrekang, Tanggal 14 September 2018.

${ }^{38}$ Misran, Kepala MTs. Ponpes Modern Darul Falah Enrekang, Wawancara, Enrekang, Tanggal 05 September 2018.
} 
b) Pengelolaan peserta didik

Peserta didik dalam satu kelas biasanya memiliki kemampuan yang berbeda, yaitu pandai, sedang dan kurang pandai. Pendidik perlu mengatur berdasarkan kemampuan dan karakteristik belajar secara invidu, kelompok atau klasikal. Keadaan seperti ini dapat dimungkinkan peserta didik dikelompokan berdasarkan metode acak, dengan tujuan agar terjadi tutor sebaya. Selama pengamatan peneliti, pendidik lebih fokus menyelesaikan materi pembelajaran ketimbang melakukan pengelolaan peserta didik, misalnya, ada peserta didik mengalami kesulitan membaca Al-Qur'an, tentu dengan tidak segan dan takut bertanya kepada teman sebayanya.

Menyangkut dengan pengelolaan peserta didik, Darwin sebagai pendidik pendidikan agama Islam Madrasah Tsanawiyah Pondok Pesantren Modern Darul Falah Enrekang mengatakan:

Selama saya mengajar di sini, beberapa kali saya lakukan pembelajaran secara kelompok, dan memang agak lebih mudah diserap oleh peserta didik materi ketimbang ceramah. Cuma memang cara ini lebih baik diterapkan pada kelas yang heterogen, yakni cerdas, sedang dan rendah serta peserta didik yang memiliki akhlak yang bagus. Jika tidak seperti itu, bisa saya katakan tidak berhasil, karena peserta didik bukan belajar, tetapi ribut dan susah dikendalikan. Apalagi saya sebagai pendidik perempuan, memiliki keterbatasan mencegah mereka jika sudah ribut, sehingga lebih banyak mereka saya berikan materi yang sifatnya dicatat, dan setelah itu saya memberikan penjelasan. ${ }^{39}$

Analisis peneliti terhadap temuan di lapangan tentang pengelolaan peserta didik seharusnya dilakukan oleh pendidik dalam proses pembelajaran lebih berkualitas, namun belum seragam pendidik melakukan pengelolaan peserta didik dalam pembelajaran dengan baik, terbukti masih ada pendidik yang tidak melakukan pengelolaan peserta didik secara terus-menerus, sehingga para peserta didik cepat bosan karena cuma mencatat dan mendengarkan ceramah tiap hari.

c) Penggunaan strategi dan metode

Pada proses pembelajaran PAI, pendidik belum banyak menerapkan sistem pembelajaran yang sifatnya variatif dan inovatif. Hal ini dibenarkan oleh informan pendidik PAI, menyatakan bahwa:

\footnotetext{
${ }^{39}$ Darwin, "Pendidik PAI", Wawancara, Enrekang, Tanggal 12 September 2018.
} 
Saya menyadari bahwa pembelajaran dengan menggunakan metode ceramah sangat membosankan bagi peserta didik, namun saya sebagai pendidik PAI tidak bisa berbuat banyak, karena jika saya menerapakan berbagai bentuk metode dalam pembelajaran, maka saya tentu menyesuaikan dengan fasilitas pembelajaran yang tersedia. Keberadaan fasilitas pembelajaran di Madrasah sangat terbatas, sehingga kurang memungkinkan untuk menerapkan berbagai metode. Paling tidak, metode yang diterapkan dalam pembelajaran PAI di sini adalah; ceramah, tanya jawab, sedangkan metode diskusi sangat jarang dilakukan, karena metode ini membutuhkan sejumlah persiapan, termasuk kesiapan peserta didik. ${ }^{40}$

Sejalan dengan keterangan di atas, informan dari pendidik PAI menyatakan, bahwa:

Sebenarnya jika dalam proses pembelajaran menggunakan metode yang beragam, akan memudahkan pendidik dan peserta didik melakukan pembelajaran, namun karena terbatasnya media pembelajaran, maka pendidik PAI menjalankan tugas sesuai dengan fasilitas yang tersedia dan kompetensi yang dimiliki. ${ }^{41}$

Bertitik tolak pada keterangan di atas, dapat disimpulkan bahwa metode ceramah masih menjadi metode yang ideal digunakan oleh pendidik PAI di Madrasah Tsanawiyah Pondok Pesantren Modern Darul Falah Enrekang dalam pembelajaran. Dalam observasi di lapangan, ditemukan bahwa sebagian besar metode yang digunakan oleh pendidik khususnya pendidik agama Islam adalah metode ceramah dan metode tanya jawab. Hal ini membuktikan bahwa keaktipan peserta didik dalam pembelajaran sangat terbatas, keterlibatannya dalam pembelajaran ketika ada ruang tanya jawab, lebih dari itu peserta didik diposisikan sebagai objek pembelajaran.

d) Jadwal kegiatan yang padat

Sistem pendidikan pondok pesantren menuntut para peserta didik, pendidik dan seluruh elemen patuh kepada aturan pondok. Hal tersebut dapat berimplikasi kepada tidak maksimalnya kegiatan pembelajaran. Berikut adalah jadwal kegiatan harian santri:

\footnotetext{
${ }^{40}$ Darwin, "Pendidik PAI", Wawancara, Enrekang, Tanggal 12 September 2018.

${ }^{41}$ Nasan, "Pendidik PAI", wawancara, Enrekang, Tanggal 14 September 2018.
} 
Tabel 4. Jadwal Kegiatan Harian di Pondok Pesantren ${ }^{42}$

\begin{tabular}{|c|c|l|}
\hline NO & WAKTU & \multicolumn{1}{c|}{ KEGIATAN } \\
\hline 1 & $04: 20-04: 40$ & Siap-siap melaksanakan sholat subuh \\
\hline 2 & $04: 40-05: 00$ & sholat subuh berjamaah dimesjid \\
\hline 3 & $05: 00-05: 45$ & $\begin{array}{l}\text { kegiatan tambahan (tahfidz, pemberian mufradat B. Arab, } \\
\text { B. Inggris) }\end{array}$ \\
\hline 4 & $05: 45-06: 45$ & mandi dan sarapan \\
\hline 5 & $06: 45-07: 00$ & siap-siap kesekolah \\
\hline 6 & $07: 00-07: 10$ & apel pagi \\
\hline 7 & $07: 10-12: 10$ & jam sekolah efektif \\
\hline 8 & $12: 10-12: 20$ & sholat dhuhur \\
\hline 9 & $12: 20-13: 10$ & istirahat dan makan \\
\hline 10 & $13: 10-15: 10$ & belajar efektif \\
\hline 11 & $15: 10-15: 20$ & istirahat \\
\hline 12 & $15: 20-15: 40$ & sholat ashar \\
\hline 13 & $15: 40-16: 00$ & mufradat dan kultum \\
\hline 14 & $16: 00-17: 30$ & Olahraga \\
\hline 15 & $17: 30-18: 10$ & istirahat dan mandi \\
\hline 16 & $18: 10-18: 30$ & sholat magrib \\
\hline 17 & $18: 30-19: 15$ & Pengajian \\
\hline 18 & $19: 15-19: 30$ & sholat isya \\
\hline 19 & $19: 30-20: 15$ & makan malam \\
\hline 20 & $20: 15-21: 45$ & belajar malam \\
\hline
\end{tabular}

Dari tabel di atas kita bias melihat bahwa mulai dari aktifitas bangun tidur sampai tidur kembali telah diatur oleh aturan pondok yang berlaku. Peserta didik menyatakan bahwa "kegiatan pondok sangat full sehingga kita susah membagi waktu untuk beljar dan beristirahat". ${ }^{43}$ Padatnya kegiatan pembelajaran di pondok dan di kelas, berimplikasi kepada tingkat kemampuan peserta didik dalam mengikuti pembelajaran.

\section{Solusi atas Problematika Pembelajaran PAI}

Identifikasi masalah, baik yang ada pada pendidik maupun peserta didik, Madrasah Tsanawiyah Pondok Pesantren Modern Darul Falah Enrekang memerlukan solusi yang tepat dan benar. Terkait problem pendidik dan peserta

\footnotetext{
${ }^{42}$ Sumber: Dokumen Pendidiks OSDF Ponpes Modern Darul Falah Enrekang Tahun 2018/2019.

${ }^{43}$ Rafika Djafar, Santriwati MTs. Ponpes Moder Darul Falah Enrekang, Wawancara, Enrekang, Tanggal 06 September 2018.
} 
didik dalam pembelajaran PAI, Misran sebagai Kepala Madrasah Tsanawiyah menyatakan bahwa:

Memang harus diakui bahwa problema pembelajaran yang terjadi di sekolah ini bukan hanya pendidikan agama Islam, tetapi hampir semua mata pelajaran. Jika ingin mengejar mutu pendidikan, maka diperlukan mencari solusi terbaik, Ke depan, saya akan melakukan beberapa upaya untuk mencari solusi atas problem pembelajaran, di antaranya adalah pembenahan kelembagaan secara menyeluruh. ${ }^{44}$

Pernyataan kepala Madrasah Tsanawiyah di atas menegaskan adanya komitmen untuk meningkatkan mutu pembelajaran. Peningkatan mutu pembelajaran penting diusung oleh seluruh pihak terkait agar dapat dilakukan secara komprehensif. Berikut dikemukakan pernyataan informan terkait solusi atas masalah pembelajaran, yakni:

a. Mendesain perangkat pembelajaran

Keberhasilan pembelajaran tergantung dari desain perangkat yang telah disiapkan sebelumnya. Pendidik sejatinya memiliki inisiasi untuk membenahi administrasi pembelajaran agar dapat menilai hasil pembelajaran dengan baik. Oleh sebab itu, masalah perangkat pembelajaran penting dicarikan solusinya agar benar-benar dapat tersedia dan menjadi rujukan pendidik dalam melaksanakan pembelajaran di kelas. terkait dengan hal tersebut, kepala Madrasah Tsanawiyah memberikan pernyataan, sebagai berikut:

Saya selaku penanggungjawab di madrasah tsanawiyah, akan mendorong setiap pendidik untuk mempersiapkan perangkat pembelajaran. Kita akan bentuk tim pengawas dan berdayakan tim tersebut sebagai bagian dari instrument penilaian. Kita juga akan dorong pendidik agar aktif mengikuti kegiatan organisasi profesi seperti MGMP dan AGPAI, aktif mengirim pelatihan bidang pembelajaran, serta mendorong pendidik agar siap studi lanjut. Yayasan sudah siap mendorong dan membantu secara finansial walaupun tidak sepenuhnya jika ada pendidik ingin lanjut studi. ${ }^{45}$

Keterangan di atas membuka ekspektasi bagi peningkatan kualitas dan komitmen pendidik dalam menyusun desain pembelajaran. Apalagi pihak yayasan siap memberikan insentif kepada pendidik yang membenahi administrasi pembelajaran.

\footnotetext{
${ }^{44}$ Misran, Kepala MTs. Ponpes Modern Darul Falah Enrekang, Wawancara, Enrekang, Tanggal 05 September 2018.

${ }^{45}$ Misran, Kepala MTs. Ponpes Modern Darul Falah Enrekang, Wawancara, Enrekang, Tanggal 05 September 2018.
} 
b. Pembenahan sarana pembelajaran

Hambatan dan sekaligus masalah dalam pembelajaran adalah keterbatasan sarana pendukung yang tersedia. Media pembelajaran berbasis TIK membantu proses pembelajaran secara efektif dan efisien. Begitu juga dengan ketersediaan laboratorium, seperti laboratorium fisika, Bahasa, dan lainnya, sangat kontributif terhadap peningkatan kualitas pembelajaran. Berdasarkan kondisi tersebut, informan menyatakan bahwa:

Yayasan sudah memahami kondisi keterbatasan sarana pondok pesantren sehingga terganggu pelaksanaan pembelajaran. Namun demikian, komitmen yayasan akan membenahi kekurangan tersebut secara berkala berdasarkan kemampuan keuangan yayasan. Hal tersebut merupakan ekspektasi pendidik ke depan, semoga segera dapat terwujud untuk membenahi sistem pembelajaran. ${ }^{46}$

Keterangan di atas menunjukkan bahwa masalah keterbatasan sarana pembelajaran maka solusinya adalah mengadakan sarana tersebut. Jika sarana terbatas maka mesti pihak pendidik memperkuat aspek lain, seperti strategi dan metode pembelajaran yang berkualitas. Namun demikian, ada sarana pembelajaran yang tidak bisa ditutupi bidang lain seperti laboratorium Fisika dan lainnya.

c. Memperbaiki pengelolaan kelas

Pengelolaan kelas yang baik dan teratur dapat menciptakan suasana pembelajaran yang menyenangkan, karena waktu belajar lebih banyak dilaksanakan dalam kelas, maka dibutuhkan penataan ruangan yang menarik untuk ditempati belajar. Darwin menjelaskan bahwa:

Saya menyadari bahwa tuntutan pendidik profesional tidak hanya memiliki keahlian mengajar, tetapi tanggung jawab pengelolaan kelas juga harus dimiliki. Pada tahun pelajaran 2019/2020 mendatang, saya sudah memprogramkan beberapa hal, termasuk pengelolaan kelas yang baik. Rancangan program itu akan saya sampaikan pada rapat awal tahun ketika masuk setelah libur mendatang. ${ }^{47}$

Selanjutnya, informan lain juga memberikan pernyataan terkait tentang pengelolaan kelas, bahwa:

Saya sejak lama berharap membenahi pengelolaan kelas dengan baik, hanya saja dibutuhkan komitmen bersama di seluruh unsur madrasah. Karena jika

\footnotetext{
${ }^{46}$ Hayatuddin, "Ketua Yayasan Pondok Pesantren Modern Darul Falah”, Wawancara, Enrekang, Tanggal 05 September 2018.

${ }^{47}$ Darwin, "Pendidik PAI", Wawancara, Enrekang, Tanggal 12 September 2018.
} 
hanya inisiatif sendiri untuk melakukan perubahan, prosesnya kurang berjalan dengan baik. Pada rapat awal tahun pelajaran, saya akan usulkan untuk melakukan pembenahan sistem pembelajaran, agar ke depan mutu pendidikan lebih meningkat ${ }^{48}$.

Pendidik PAI mulai menyadari urgensi dan relevansi pembenahan sistem pembelajaran, utamanya pengelolaan kelas. Kesadaran tersebut dapat menggugah mendesaknya upaya perbaikan dan keterlibatan seluruh pihak. Hal tersebut sebagai tanggung jawab moral sebagai pendidik untuk membenahi pengelolaan kelas dengan baik.

d. Menata pengelolaan peserta didik

Peserta didik dalam setiap kelas memiliki karakteristik, budaya, suku, agama, status sosial, dan latar belakang keluarga yang berbeda. Untuk menciptakan proses pembelajaran yang produktif dan menyenangkan, pendidik perlu ada upaya mengatur peserta didik. Terkait dengan upaya perbaikan pengelolaan peserta didik, salah seorang informan menyatakan bahwa:

Masalah dalam pembelajaran selama ini adalah eksistensi peserta didik yang heterogen dari segi psikologis. Jumlah 28 sampai 33 dalam satu kelas dengan karakteristik dan kemampuan yang beragam menjadi masalah tersendiri dalam pembelajaran. Namun ke depan, penting bagi pendidik PAI sudah merencanakan upaya perbaikan pengelolaan peserta didik. Karena bagaimanapun keberhasilan pembelajaran itu tergantung pada kesungguhan pendidik untuk mendesain pembelajaran yang lebih baik. ${ }^{49}$

Kesemrawutan pengelolaan peserta didik dalam setiap pembelajaran merupakan solutif atas masalah dalam pembelajaran. Untuk itu, seluruh stakeholder di Madrasah Tsanawiyah Pondok Pesantren Modern Darul Falah memberikan layanan prima kepada peserta didik.

e. Mengembangkan strategi dan metode pembelajaran yang tepat

Temuan sebelumnya bahwa masalah strategi dan metode pembelajaran masih berakar pada pendidik di pondok pesantren. Pendidik dituntut memperkaya strategi dan metode pembelajaran agar peserta didik dapat belajar dengan baik dan tercapai tujuan secara efektif dan efisien. Salah seorang informan pendidik PAI menyatakan bahwa:

\footnotetext{
${ }^{48}$ Nasan, "Pendidik PAI", wawancara, Enrekang, Tanggal 14 September 2018.

${ }^{49}$ Misran, Kepala MTs. Ponpes Modern Darul Falah Enrekang, Wawancara, Enrekang, Tanggal 05 September 2018.
} 
Pendidik wajib memperkaya strategi dan metode pembelajaran di dalam kelas. Pendidik akan enjoy dan menikmati dalam mengajar jika dapat menerapkan strategi dan metode pembelajaran dengan baik. Akan datang sejatinya mengembangkan strategi dan metode yang variatif, apalagi pihak madrasah sudah ingin meningkatkan kualitas pendidik. 50

Keterangan di atas, dapat disimpulkan bahwa pendidik khususnya PAI telah menyadari bahwa menggunakan strategi dan metode yang bervariasi dalam pembelajaran, selain memudahkan pendidik dalam menyampaikan materi pelajaran, dan juga membuat peserta didik aktif dalam belajar. Untuk itu, pendidik sejatinya menyiapkan diri untuk melakukan perubahan ke arah pembelajaran yang lebih baik, agar hasil pembelajaran lebih meningkat dan lebih baik kualitasnya.

\section{f. Peningkatan Pembinaan Disiplin}

Disipilin merupakan aspek yang turut menentukan proses kelancaran pembelajaran. Jika pengelolaan suatu lembaga pendidikan menerapkan peraturan sekolah yang diatur dalam bentuk tata tertib dijadikan sebagai payung hukum untuk penegakan disipilin, maka pendidik lebih mudah melakukan pengelolaan kelas untuk menciptakan pembelajaran yang aktif, inivatif, kreatif, efektif dan menyenangkan.

Sehubungan dengan keterangan kepala sekolah di atas, Darwin sebagai pendidik PAI menyatakan bahwa:

Beberapa upaya yang mesti dilakukan untuk meningkatkan pembinaan disiplin, yaitu: (1) setiap pendidik ada yang bertugas setiap hari pada apel pagi mencatat setiap peserta didik yang lambat, catatan tersebut diserahkan kepada masing-masing wali kelas dan kesiswaan. Selain absen wali kelas, setiap pendidik mata pelajaran mencatat peserta didik yang alpa, terlambat dan bolos. Selanjutnya perkembangan disiplin peserta didik dilaporkan kepada kesiswaan dan kekampusan untuk ditindaklanjuti. 2. Mengundang orang tua peserta didik untuk berkonsultasi jika ada anak-anak mereka yang bermasalah yang selanjutnya akan diberikana arahan. ${ }^{51}$

Setelah mengamati pembinaan disiplin sekaligus dibandingkan dengan hasil wawancara kepada informan, maka dapat dikatakan bahwa pembinaan disiplin di Madrasah Tsanawiyah Pondok Pesantren Modern Darul Falah menunjukkan adanya usaha ke arah yang lebih baik. Hal ini diindikasikan oleh pendidik masuk sekolah tepat waktu, dan peserta didik terlambat masuk sekolah, pendidik sebagai

\footnotetext{
${ }^{50}$ Darwin, "Pendidik PAI", Wawancara, Enrekang, Tanggal 12 September 2018.

${ }^{51}$ Darwin, "Pendidik PAI", Wawancara, Enrekang, Tanggal 12 September 2018.
} 
pendidik jaga memberi sanksi berupa membersihkan ruangan atau sanksi-sanksi lain yang membuat peserta didik jera untuk tidak mengulangi kesalahannya.

Pembelajaran PAI menegaskan pendidik sebagai penentu utama tercapainya tujuan yang diharapkan. Efektivitas dan efisiensi pembelajaran dapat terwujud jika pendidik memenuhi prosedur pelaksanaan pembelajaran. Kualitas atau mutu pembelajaran PAI apabila pendidik memiliki kompetensi dan dedikasi dalam melaksanakan pembelajaran. Sosok pendidik memiliki ciri-ciri yang diidealkan dalam bertugas, yaitu, a. Mencintai dirinya sebagai sosok pendidik, b. Bersikap adil terhadap peserta didiknya, c. Selalu sabar dan tenang, d. Mempunyai wibawa, e. Bersikap menggembirakan dan menyenangkan, f. Bekerjasama dengan pendidik yang lainnya. ${ }^{52}$ Kriteria pendidik tersebut dinilai relevan dikembangkan di Madrasah Tsanawiyah Pondok Pesantren Modern Darul Falah, sehingga kegiatan pembelajaran dapat berjalan sesuai ekspektasi yang ada.

Pendidik PAI menjadi solutif bagi peserta didik yang dinilai bermasalah. Pendidik dituntut menunjukkan keberpihakan, totalitas, dan komitmen menjalankan tugasnya. Pendidik harus berpacu dalam pembelajaran dengan memberikan kemudahan belajar bagi seluruh peserta didik, agar dapat mengembangkan potensinya secara optimal. Dalam hal ini pendidik harus kreatif, profesional, menyenangkan, dan mampu memahami karakteristik peserta didiknya. ${ }^{53}$ Tuntutan dan kewajiban pendidik yaitu meningkatkan kompetensinya, mengasah kemampuan mengajar, mengembangkan kreasi dan inovasi pembelajaran, dan sebagainya.

Pendidik dituntut lebih kreatif, inovatif, tidak menjadi sumber satu-satunya proses pembelajaran (teacher centered), menempatkan peserta didik tidak hanya sebagai obyek belajar tetapi juga sebagai subyek belajar dan pada akhirnya bermuara pada proses pembelajaran yang menyenangkan, bergembira, dan demokratis yang menghargai setiap pendapat sehingga pada akhirnya substansi

\footnotetext{
${ }^{52}$ Hartono, "Pendidik dan Peserta Didik dalam Perspektif Filsafat Pendidikan Islam", Jurnal Potensia, vol.13, Edisi 1, Januari-Juni. 2014.

${ }^{53}$ Ilin Nurhamidah, "Problematika Kompetensi Pedagogi Pendidik Terhadap Karakteristik Peserta Didik". Jurnal Teori dan Praksis Pembelajaran IPS, Volume 3, No.1, 2018, h. 28. http://dx.doi.org/10.17977/um022v3i12018p027
} 
pembelajaran benar-benar dihayati. ${ }^{54}$ Madrasah Tsanawiyah Pondok Pesantren Modern Darul Falah memiliki pendidik yang menunjukkan komitmen untuk maju dan kompetitif. Pondok pesantren ini berada di tengah kota Enrekang, sejatinya menjadi par of excellence bagi lahirnya peradaban Islam. Ekspektasi tersebut dapat terwujud jika pendidiknya komitmen secara kolektif untuk meningkatkan kualitas diri dan pembelajaran, khususnya PAI.

Ukuran kualitas dan mutu pembelajaran dapat dilihat dari aspek proses dan hasil. Proses pembelajaran yang efektif dapat berimplikasi kepada hasil yang optimal. Oleh sebab itu, pendidik harus memahami peserta didik sebagai subjek dan objek pembelajaran, baik secara filosofis, teologis, psikologis, sosiologis, maupun antropologis. Hakikat peserta didik adalah individu yang membutuhkan bantuan agar mereka dapat mengenal Allah yang menciptakan mereka, sehingga mereka dalam setiap aktivitasnya senantiasa selalu berada di jalan Allah yang diridhai. ${ }^{55}$ Pengetahuan terhadap peserta didik menjadi input berharga bagi pendidik dalam mendesain perangkat dan melaksanakan pembelajaran.

Pengetahuan peserta didik secara substantive dapat dilihat dari aspekaspek kebutuhan dalam pembelajaran. Peserta didik termotivasi mengikuti pembelajaran jika sesuai dengan kebutuhannya. Hal tersebut sejatinya menjadi prioritas utama pendidik dalam menelaah kebutuhan peserta didik dalam pembelajaran. Kebutuhan ini meliputi kebutuhan fisik, kebutuhan sosial, kebutuhan untuk mendapatkan status, kebutuhan mandiri, kebutuhan untuk berprestasi, kebutuhan ingin disayangi dan dicintai, kebutuhan curhat meluapkan perasaannya, serta kebutuhan kebutuhan mendapatkan arti filosofis dari hidup. ${ }^{56}$

Interaksi antara pendidik dan peserta didik semestinya berjalan efektif, efukatif, dan kondusif. Dalam situasi pembelajaran di kelas, pendidik hendaknya berperan seperti BK kepada peserta didiknya, dengan memahami pribadi dan lingkungan peserta didik, sebaiknya pendidik merencanakan dan menyelenggarakan proses pembelajaran sesuai karakteristik peserta didiknya dengan penuh keikhlasan dan tanggung jawab. ${ }^{57}$ Keakraban dan kesepahaman

\footnotetext{
${ }^{54}$ Soifullah, dkk., "Strategi Peningkatan Mutu Pendidikan di Sekolah". Jsh Jurnal Sosial Humaniora. Vol. 5, No. 2, November 2012, h. 211.

${ }^{55}$ Musaddad Harahap, "Esensi Peserta Didik dalam Perspektif Pendidikan Islam". Jurnal AlThariqah, Vol. 1, No. 2, Desember 2016, h. 154.

${ }^{56}$ Abdul Aziz, "Komunikasi Pendidik Dan Peserta Didik Dalam Pendidikan Islam", Mediakita Vol. 1, No. 2 Juli 2017), h.: 176.

${ }^{57}$ Ilin Nurhamidah, "Problematika Kompetensi Pedagogi Pendidik Terhadap Karakteristik Peserta Didik". Jurnal Teori dan Praksis Pembelajaran IPS, Volume 3, No.1, 2018, h. 37. http://dx.doi.org/10.17977/um022v3i12018p027
} 
antara pendidik dan peserta didik dapat berimplikasi kepada ketercapaian dan ketuntasan pembelajaran PAI di kelas. Dengan demikian, problem mendasar pembelajaran PAI dapat dilihat dari aspek sejauhmana keakraban atau kedekatan pendidik dengan peserta didik, baik di dalam kelas maupun di pondok.

\section{E. Kesimpulan}

Berdasarkan pembahasan di atas, maka ditarik kesimpulan, sebagai berikut:

1. Problem pendidik pada Madrasah Tsanawiyah Pondok Pesantren Modern Darul Falah Enrekang adalah Kompleksitas karakter peserta didik; Terbatasnya waktu pembelajaran dan materi padat; Penguasaan pendidik terhadap materi pelajaran; Ketersediaan administrasi pendidik; Keterbatasan sarana dan prasarana pembelajaran; Pendidik terbatas menguasai strategi dan metode pembelajaran; Rendahnya keikutsertaan pendidik mengikuti pelatihan dan pertemuan ilmiah; dan Pendidik memiliki waktu yang padat membina peserta didik di pondok pesantren. Problem peserta didik pada Madrasah Tsanawiyah Pondok Pesantren Modern Darul Falah Enrekang adalah Strategi dan metode pembelajaran yang monoton; Peserta didik yang tidak terjangkau nalarnya terhadap pembelajaran; Peserta didik belum mendapatkan cara menghafal; Motivasi bersaing dinilai rendah karena peserta didik yang tidak majemuk; dan Lambat masuk belajar karena terbatas sarana di pondok.

2. Factor pendukung dan penghambat pembelajaran PAI, yaitu (a) faktor pendukung meluputi: Sistem pembelajaran 24 jam; Dana bantuan dari Yayasan; dan Kegiatan ektrakulikuler; dan (b) factor penghambat, meliputi: pengelolaan kelas; pengelolaan peserta didik; penggunaan strategi dan metode; jadwal kegiatan pondok yang padat

3. Solusi atas problem pendidik dan peserta didik dalam pembelajaran PAI di Madrasah Tsanawiyah Pondok Pesantren Modern Darul Falah Enrekang adalah Mendesain perangkat pembelajaran; Pembenahan sarana pembelajaran; Memperbaiki pengelolaan kelas; Menata pengelolaan peserta didik; Mengembangkan strategi dan metode pembelajaran yang tepat; dan Peningkatan Pembinaan Disiplin. 
St Wardah Hanafie, Muhammad Siri Dangnga, Abdul Halik \& Jabal Rahmah

\section{DAFTAR PUSTAKA}

Achmadi (2005). Ideologi Pendidikan Islam. Cet. I; Yogyakarta: Pustaka Pelajar.

Arikunto, Suharsimi (2006). Prosedur Penelitian, Suatu Pendekatan Praktik. Cet. XIII; Jakarta: Rineka Cipta.

Asmani, Jamal Ma'mun (2012). Buku Panduan Internalisasi Pendidikan Karakter di Sekolah. Yogyakarta: Diva Press.

Atika, Surya (2014). "Pelaksanaan Pendidikan Karakter Religius, Cinta Tanah Air, dan Disiplin) di SLB Al-Ishlah Padang". E-JUPEkhu (Jurnal Ilmiah Pendidikan Khusus). Volume 3, nomor 3, September.

Aziz, Abdul (2017). "Komunikasi Pendidik Dan Peserta Didik Dalam Pendidikan Islam", Mediakita Vol. 1 No. 2 Juli.

Burhan Bungin (2005). Analisis Data Penelitian Kualitatif: Pemahaman Filosofis dan Metodologis ke Arah Penguasaan Model Aplikasi, Edisi I. Cet. III; Jakarta: PT. RajaGrafindo Persada.

Departemen Agama RI Direktorat Jendera Pendidikan Islam (2006). UndangundangRepublik Indonesia Nomor 14 Tahun 2005 Tentang Pendidik dan Dosen serta Undang-undangRepublik Indonesia Nomor 20 Tahun 2003 Tentang Sisdiknas. Jakarta.

Departemen Agama RI. (2009). Al-Quran dan Terjemahnya. Semarang: Toha Putra.

Desmita (2009). Psikologi Perkembangan Peserta Didik: Panduan Bagi Orang Tua Dan Pendidik Dalam Memahami Psikologi Anak Usia SD, SMP, Dan SMA. Cet. I:Bandung PT. Remaja Rosda Karya.

Gall, Gall, \& Borg. (2003). Educational Research: An Introduction. $7^{\text {th }}$ Edition, Boston: Allyn and Bacon.

Hanafiah, Nanang dan Cucu Suhana (2010). Konsep Strategi Pembelajaran .Cet. 2; Bandung: Refika Aditama.

Harahap, Musaddad (2016). "Esensi Peserta Didik dalam Perspektif Pendidikan Islam". Jurnal Al-Thariqah, Vol. 1, No. 2, Desember.

Hartono (2014) "Pendidik dan Peserta Didik dalam Perspektif Filsafat Pendidikan Islam", Jurnal Potensia, vol.13, Edisi 1 Januari-Juni.

Hidayatullah, M. Furqon (2010). Pendidikan Karakter: Membangun Peradaban Bangsa. Surakarta: Yuma Pustaka.

Kementrian Pendidikan Nasional (2010). Pengembangan Pendidikan Budaya dan Karakter Bangsa: Pedoman Sekolah. Jakarta: Puskur Balitbang Kemendiknas

Khatimah, Khusnul (2016). "Model Manajemen Pendidikan Karakter Religius di SDIT Qurrota A'yun di Ponorogo", Muslim Heritage, Vol. 1, No. 2.

Majid, Abdul (2011). Perencanaan Pembelajaran; Mengembangkan Standar Kompetensi Pendidik. Cet. VII; Bandung: PT. Remaja Rosdakarya.

dan Jusuf Muzakkir (2010). Ilmu Pendidikan Islam. Cet. III; Jakarta: Kencana.

Moleong, Lexy J. (2009). Metodologi Peneliian Kualitatif, edisi revisi. Cet. XXVI; Bandung: PT. Remaja Rosdakarya. 
Problems of Educators and Students in Learning Islamic Religious Education at Mts Pondok Darren Modern Darul Falah, Enrekang District

Muhaimin (2009). Rekonstruksi Pendidikan Islam. Ed. I. Cet. I; Jakarta: Rajawali Pres.

Nurhamidah, Ilin (2018). "Problematika Kompetensi Pedagogi Pendidik Terhadap Karakteristik Peserta Didik". Jurnal Teori dan Praksis Pembelajaran IPS, Volume 3, No.1. http://dx.doi.org/10.17977/um022v3i12018p027

Soifullah, dkk. (2012) "Strategi Peningkatan Mutu Pendidikan di Sekolah". Jsh Jurnal Sosial Humaniora. Vol. 5, No. 2, November.

Sugiyono (2010). Metode penelitian Pendidikan; Pendekatan Kuantitatif, Kualitatif, dan R\&D.Cet. IX; Bandung: Alfabeta.

(2011). Metode Penelitian Kuntitatif, Kualitatif, dan Kombinasi (Mixed Methods). Cet, I; Bandung: Alfabeta.

Sukmadinata, Nana Syaodih (2004). Kurikulum dan Pembelajaran Kompetensi. Bandung: PT Remaja Rosdakarya.

Susilo, Muhammad Joko (2008). Kurikulum Tingkat Satuan Pendidikan: Manajemen Pelaksanaan dan Kesiapan Sekolah Menyongsongnya,Cet. III; Yogyakarta: Pustaka Pelajar, 2008.

Sutrisno dan Muhyidin Al Barobis (2012). Pendidikan Islam Berbasis Problem Sosial. Jogjakarta: ArRuzz Media,

Usman, Muh. Uzer (2011). Menjadi Pendidik Profesional. Cet. XXV; Bandung: PT. Remaja Rosdakarya Offset.

Zubaiedi (2011). Desain Pendidikan Karakter: Konsepsi dan Aplikasinya dalam Lembaga Pendidikan. Jakarta: Kharisma Putera Utama. 